\title{
Woda dekoracyjna w śródmiejskich przestrzeniach publicznych Barcelony
}

\author{
Decorative water features in public \\ spaces in the centre of Barcelona
}

Streszczenie

Woda towarzyszyła architekturze od zarania dziejów, była jednym z podstawowych warunków umożliwiających budowe

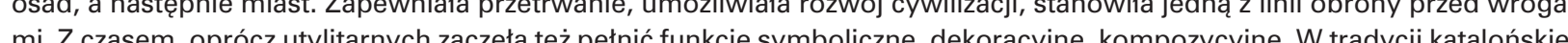
najbardziej prestiżowymi przestrzeniami publicznymi były niekoniecznie place, ale raczej las ramblas. To charakterystyczne typologicznie dla tamteiszej kultury urbanistycznej podtuzine promenady wysadzane drzewami, zakładane wzdłuz rzek i potoków, wokół których rozwijały sie miasta. Te cieki wodne, niegdyś użytkowe, a potem coraz bardziej zanieczyszczone, były nastepnie ukrywane pod posadzkami. Z czasem także inne, bardziej dekoracyjne sposoby wykorzystania wody przeniknety do Katalonii z innych cześci Europy. Parki, skwery i place wyposażone w dekoracyjne elementy wodne to miejsca charakterystyczne w krajobrazie śródmiejskim Barcelony i innych miast. W artykule zostanie omówionych kilka realizacijz lat 1899-2015.

\section{Abstract}

Water has been accompanying architecture since the dawn of time. It was one of the fundamental conditions enabling to of defence lines against enemies. In time, besides utilitarian functions it started to fuffil symbolic, decorative, and compositional ones. In the Catalan tradition the most prestigious public spaces where not necessarily squares, but rather las ramblas. These are longitudinal tree-lined promenades, typologically characteristic for the local urban culture, designed along rivers and streams, around which towns would develop. These watercourses, once fulting utilitarian functions, in time becoming more and more polluted, were subsequently hidden underneath the ground. Over the ages also other, more decorative ways of making use of water reached Catalonia from other parts of Europe. Parks, squares, and piazzas equipped with decorative water features arechar $1899-2015$. projects from the years $1899-2015$

Słowa kluczowe: woda w mieście, park, przestrzén publiczna, urbanistyka krajobrazu, krajobraz miejski, Barcelon

Keywords: water in the city, park, public space, urban planning of landscape, urban landscape, Barcelona

\section{Wprowadzenie}

Woda towarzyszyła architekturze od zarania dziejów, była jednym z podstawowych warunków umożliwiających budowę osad, z których następnie rozwijały się miasta. Zapewniała przetrwanie, umożliwiała rozwój cywilizacji, stanowiła jedna z linii obrony przed wrogami. Z czasem, oprócz utylitarnych zaczęła tez pełnic funkcje symboliczne, dekoracyjne, kompozycyjne'. W przypadku Barcelony woda miała niebagatelny wpływ na powstanie miasta. Była to przede wszystkim woda morska- starożytni założyciele osady² szukali dogodnego, osłoniętego od wiatrów, bezpiecznego portu. Do prawidłowego funkcjonowania miasta konieczna była wszakże również woda słodka- spływająca licznymi strumieniami ze wzgórz Collserola i użyźniająca Nizinę Barcelońską, stanowią-
Introduction

Wren accompanying architecture since ditions enabling to build settlements, which subse quently developed into towns. It secured survival; it enabled the development of civilisations; it constituted one of defence lines against enemies. In time besides utilitarian functions it started to fulfil also case of Barcelona, water had a consideranes'. on the city's coming into being. Most of all, it was the sea water - ancient founders of the settlement ${ }^{2}$ were looking for a convenient, safe port, protected agains winds. Fresh water, however, was necessary, too, for the town to function properly-it llowed down in nu- cą alimentacyjne zaplecze metropolii aż do drugiej połowy XIX wieku. Miedzy czasie strumienie te pomogly w rozwoju przemysłu włókienniczego, który przyczynił się do ponownego ${ }^{3}$ okresu świetności i prosperity w dziejach Barcelony, który nastapił w XIX wieku i pierwszych dekadach ubiegłego stulecia. Od stuleci jako granice terytorium miasta uważano pasmo górskie Collserola, Morze Śródziemne i dwie rzekiBesós i Llobregat, do których zwarta tkanka miejskich kwartałów dotarła dopiero w wieku XX4, a nawet je przekroczyła wspóttworząc obecnie pol nym charakterze ${ }^{5}$

Rambla jako szczególny przypadek historycznej przestrzeni publicznej

publiczei jo szczén W tradycji katalonsiej najbaciej prestiżowymi przestrzeniami publicznmi byly niekoniecznie place, czy najczęsciej kręte uhce, ale raczej las ramblas. To charakerystyczne typologicznie dla tamtejszej kultury urbanistycznej podłuzne promenady wysadzane drzewami, zakladane wzdłuz rzek i potoków, przy ktorych rozwily się miasta. Coraz bardziej zanieczyszczone, niegdyś użytkowe cieki wodne, były następnie przekrywane posadzkami, co przyczyniało się do powstania podłużnej przestrzeni wykorzystywanej jako miejsce spotkań, handlu, uroczystości religijnych i świeckich. Najbardziej znaną sekwencja takich wnętrz urbanistycznych jest barcelońska promenada Las Ramblas w Ciutat Vella 6 . Powstała ona w oparciu o strumień obmywający zachodnie mury średniowiecznego miasta ${ }^{7}$, który z czasem zamienił się w ściek i został ukryty pod posadzką. Obecnie to najbardziej rozpoznawalna przestrzen publiczna w Barcelonie, w dużej mierze opanowana przez turystów.

Pomimo to symboliczna rola i ranga rambli w katalońskiej tradycji jest bardzo duża. Powstawały od czasów średniowiecza, przez nowożytnośc, po wiek XIX8. Realizowane sa on nadal jako gtówne promenady nawet w nowych, odległych cześciach metropolii (Rambla de Prim, Rambla de odleglych czessciach to jak ja ka

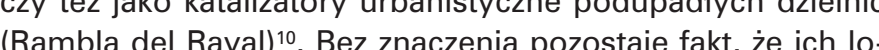
kalizaci nie wizze sie już z istniejacymi niegdyś strumieniami,

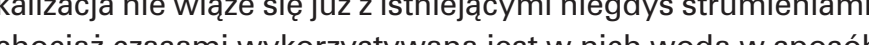
dekoracy y. Tym nizy dekoraczin. Tym nizniej prena jest w nich woda w sposob rzyszy zielen wysoka, niezwy le cenna w przegnzanej, zanieczyszczonej Barcelonie. Wspoltworza czyte we elementy budujące kompozycje unbanistycznal masta. W zaležności od wybranej teoril można uznac je za elementy liniowe lub granice pomiędzy rejonami miasta, ale kón same bezsprzecznie tworzą odrębny typ, który można by nazwać „liniowymi elementami węzlowymi . Ogniskują one w sobie bowiem aktywność społeczną mieszkańców miasta lub jego, sąsiadujących z ramblami dzielnic. Pełnią też, podobnie jak na przestrzen wieków, rolę traktów komunikacyjnych.

Krótka charakterystyka typowej tkanki urbanistycznej Barcelony- Eixample

Przeludnienie oraz fatalne warunki higieniczno-sanitarne panujące w połowie XIX wieku wewnątrz przegęszczonych kwartałów starego miasta doprowadziły, podobnie jak w wie-

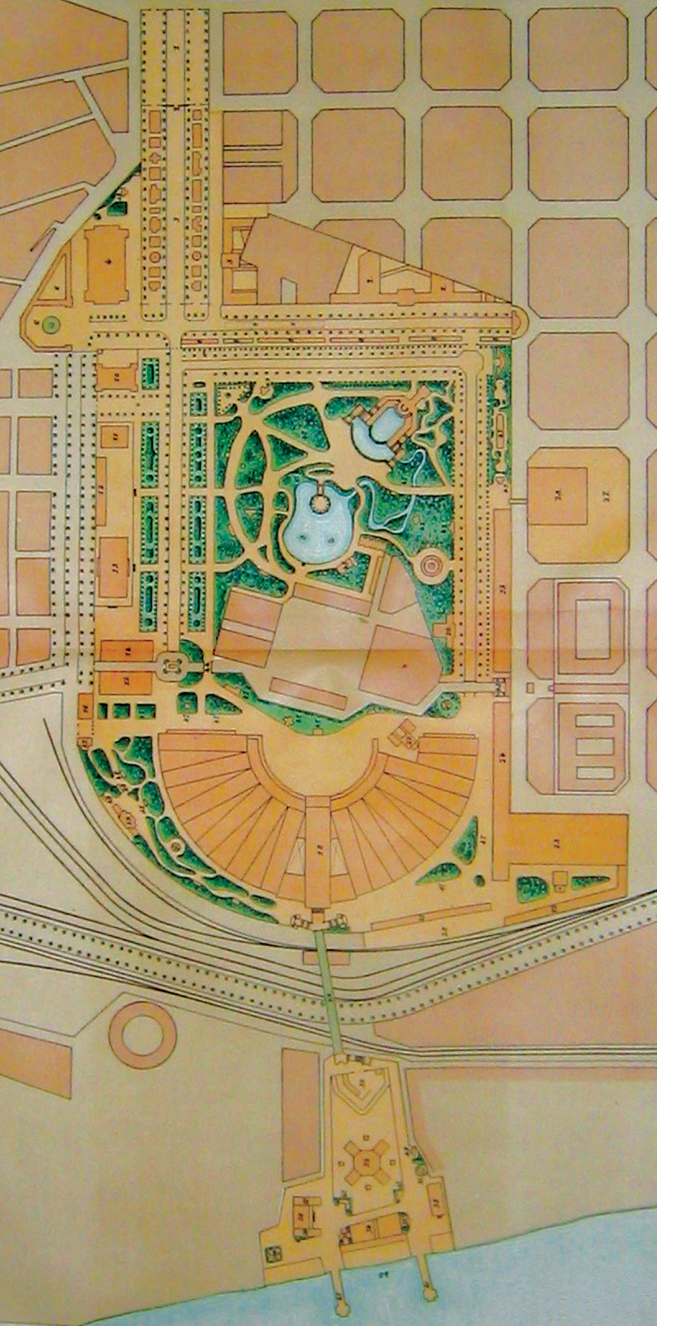

II. 1. Plan Wystawy Światowej z 1888 roku ukazuje go
jako obszar węzłowy pomiędzy historycznym centrum a ortogonalnymi kwartałami Eixample - żródto: https versal-de-barcelona-1888-3 (dostep 15.01.18) / The Map
of the World's Fair from 1888 depicts it as a hub area be
twen the historical city centre and the orthogonal quars. iween the historical city centre and the orthogonal quar-
ters of Eixample- source: https://cuinadel19.wordpress com/2013/08/18/lexposicio-units
-access on 15 January 2018

dated the Barcelona Plain, constituting the alimenary basis of the metropols even to the second half of the 19 "' century. In the meantime, these streams try, contributing to yet another ${ }^{3}$ golden age and ptry, contributing to yet another
riod of polden age and pefell on the $19^{\text {th }}$ century and the first decades of the last century. For ages the limits of the territory of the city were demarcated by the Collserola mounthe rivers by the compat tisue of tributing to the today's polycentric metropolis of quite a unique character

Rambla as a Special Case of Historical Public Space

Catalan tradition, the most prestigious public spaces were not necessarily squares or most often
winding streets, but rather las ramblas. These are longitudinal tree-lined promenades, typologically characteristic for the local urban culture, designe along rivers and streams, around which town 


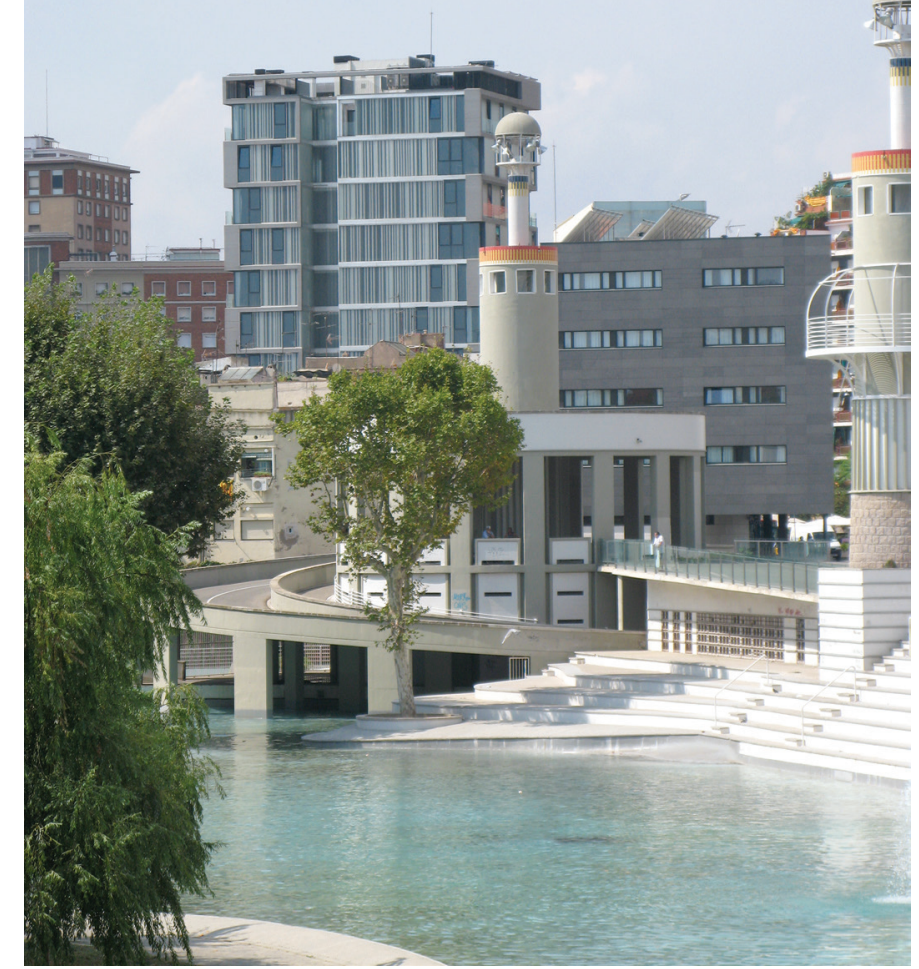

II. 16. Elementy zwiazane $z$ komunikacyina obstuga dworca udato sie umie-
jetnie zintegrować $z$ parkowym zatoziniem wodnym - fot. autor $/$ Elements
providing access to the ralway stations have been sucessfully integrated with jetnie zintegrować $z$ parkowym zatożeniem wodnym - fot. autor / Elements
providing access to the railway stations have been successfully integrated with
the water feature in the park - photo: the Author

palm, które obecnie po ponad stu latach stały się domem dla sprowadzonych do Barcelony $\mathrm{w}$ drugiej połowie $\mathrm{XX}$ wieku z Argentyny papug ${ }^{25}$, ktorych populacja w mieście wciąż wzrasta. W katalonskim klimacie, i tak wilgotniejszym od tego panującego w centralnej i południowej Hiszpanii, duże akweny wodne należą do rzadkości. Zrealizowane w parku staw (oferujący przejażdżki tódką) i kaskada z monumentalną fontanna ${ }^{20}$ stały się więc synonimem luksusu i wysokich możliwości technologicznych katalońskiej myśli inżynieryjnej. Stanowiły one bardzo dużą atrakcję na przełomie stuleci i do dzisiaj należa do najbardziej charakterystycznych i najczęściej fotografowanych przez turystów miejsc w Parc de la Ciutadella. W parku znajduje sie kilka charakterystycznych obiektów, zaprojektownduprzez czołowych twórców epoki, które zostały po Wystawien czy teź śm czy teź św południową i wschodnia część parku zajmuje ogród zoologiczny, wówczas jeden z najnowocześniejszych w Europie ${ }^{29}$.

\section{Parc de l'Espanya Industrial}

Koniec dyktatury Franco w latach 70. ubiegłego wieku, a następnie przystąpienie Hiszpanii do Wspólnoty Europejskiej zaowocowały ogromnymi dotacjami na rozwój infrastruktury oraz rewitalizację zdegradowanych obszarów w miastach. W 1992 roku zorganizowano dwa globalne wydarzenia, które przyczynity się do unowocześnienia kraju30, a szczególnie miast-gospodarzy i ich regionów metropolitarnych. Chodz o Wystawę Światową w Sewilli oraz o Letnie Igrzyska Olimpijskie w Barcelonie. W ramach przygotowań do tych drugich, w latach 80. XX wieku w mieście wdrożono szereg projek- metropolises $^{20}$. And although it has the highest number of trees amongst Medilerichean cities, most of all these are trees which line traffic parks out of those assumed in the plan of Eixample were executed. Several others came into being, and since the 1990s more and more territories have been assigned to greenery ${ }^{22}$. Despite problems relating to supplying the metropolis with water, growing more and more serious, in some .

\section{Parc de la Ciutadell}

is referred to as the city of grobal events. One of the first events of the kind was

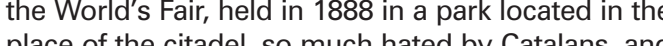
place of the citadel, so much hated by Catalans, and itary grounds were handed over to the city in 1869 , it was decided to turn the territory of the fortress into a public park - the first of this size in Barcelona. The plan of Parc de la Ciutadella was created in 1873 by Josep Fontsere, and its implementation lasted 15 years, until the opening of the World's Fair. The design introduced two large waterbodies - a centrally and a monumental, Neo-Baroque cascade in the northern corner of the park (at the end of one of the main urban axes of Eixample - Av. Meridiana). The concept of development of the park is based on classical principles of composition - several axes (seccio) connecting the main streets at its opposite sides and tral waterbody, which break their monotony

Never before had such a vast green area24, let alone so attractively arranged, been opened to the public. Many flora species, including palm trees, were planted within the perimeter of the park. Today, after over a century, they have become home for parrots brought to Barcelona from Argentina in lation has been constantly growing in the city. In the Catalan climate, which is still more humid than the climate of the central and southern Spain, large waterbodies are a true rarity. The pond (offering boat rides) and the cascade with a monumenta fountain $2^{20}$ built in the park became, therefore, a tothe Catalan engineering thought. They were a hug attraction at the turn of the century, and to this day they are one of the most characteristic sites in Parc de la Ciutadella, most often photographed by tourists. In the park there are several characteristic structures, designed by leading designers of or teptiving wh th were left leading designers of or testifying to the earlier, military history of this
place, which still fulfil important functions ${ }^{28}$. Since the 1940s the southern and eastern part of the park has been occupied by a zoological garden, at the time one of the most modern zoos in Europe ${ }^{29}$.

\section{Parc de l'Espanya Industrial}

The end of Franco's dictatorship in the 1970s, and resulted in huge subsidies formmunity by Spain infrastructure and revitalisation of development of in cities. In 1992 two global events were organised tów, w tym także takich, które niezwiązane były bezpośredprowadzonych w pracy rozważań były projekty rewitalizac $\mathrm{i}_{\text {„upiększania" }}{ }^{32}$ przestrzeni publicznych. W ich ramach zain cjowano powstanie wielu terenów zielonych, $w$ tym skwerów i miejskich parków, których w zamieszkanym przez blisko miliony osób mieście ${ }^{33}$ wciaż brakowało. W niektórych z nich przewidziano także dekoracyjne założenia wodne.

Jednym z najwiekszych w Barcelonie pozostaje do dzisia Jednym z rajzicis do dzisia dustrial. Sam park zaprojektowano jako rewitalizacje czés col nych dworcow ko jowych. Esty ó je jest do w w ckich w Barclonie. Dziek proszych zwycleczw wuchow wiejscu dawnego minna nie pows pro w lach 70 . XX wieku planowane przez dew noperw osiede mieszaniowe. Doskonale zlokalizowany pod względem dostępności teren został przekazany miastu, a park został otwarty juz w okresie przygoto-

Znaczną część, bo blisko $1 / 3$ obszaru zajmuje monumentalny basen z fontannami i posągiem Neptuna, który oddziela zielon założenie parkowe od ruchliwej, położonej ponadto kilka metrów wyżej, ulicy na tyłach dworca. W projekcie można odnaezc charakterystyczne dla poźno-postmodernistycznej estetyk elementy zagospodarowania, takie jak stylizowane kominy - latarnie morskie, czy też zjeżdżalnia w kształcie żelaznego smoka, ewidentnie nawiązujajca do tradycji barcelońskiej secesji (modernisme) i czołowych projektów tamtej epoki36. Poprowadzon na poziomie dworca, kilka metrów ponad wodą i zielenią parku pasarella pełni rolę skrótu dla pieszych i rowerzystów pomiędzy węzłem intermodalnym a Plaça de Herenni- jedną z głównych przestrzeni publicznych dzielnicy Sants. Dzięki kreatywnemu wykorzystaniu istniejącej różnicy poziomów teren parku jest łatwo dostepny dla lokalnych mieszkańców, natomiast jest wháciwie niewidoczny dla użytkowników dworca. Sprawi ziasciwimo trudnego i uciażliwego sasiedztwa ${ }^{37}$ może petnic ze polnc re paseny vé de l'Espanya In veló dez lEsspano zawody w podnoszeniu ciężáw.

\section{Podsumowanie}

Barcelona to miasto zwarte, w którym przegęszczona tkanka miejska sąsiaduje bezpośrednio z naturalnymi (bądź tylko w niewielkim stopniu przekształconymi przez człowieka) terenami zielonymi w Parku Narodowym prez cźónche collsewa zielonymi w Parku Narodowym na wzgórzach CollseMontjuic oraz bezmiarem wód Morza Śródziemnego. Być Montjuic oraz bezmiarem wod Morza Sródziemnego. Byc może dlatego zielen nie odegrała kluczowej roli w kształtowaniu struktury urbanistycznej miasta w ciągu ostatnich dwóch stuleci, a miejskie parki należały do rzadkości ${ }^{38}$. I to pomim szczytnych, odmiennych założen, jakie zawierat w sobie pierwotny plan rozszerzenia z 1859 roku. Tereny rolnicze stanowiace zaplecze miasta przez wiele wieków, zostały niemal całkowicie zabudowane. Towarzyszące im naturalne i sztuczne cieki which contributed to modernisation of the coun$t^{2} y^{30}$, and particularly of the host cities and their in Sevilltan regions. These were the World's Fair in Sevile, and he Summer wympic Games in Baatter in the 1980s a number of projects were implemented in the city, including ones which were not directly connected with the Olympic venues ${ }^{31}$ Particularly interesting for this paper were projects of revitalising and 'beautifying's2 public spaces.

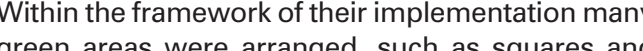
municipal parks, which were still scarce in the city inhabited by nearly 2 million people ${ }^{33}$. Decorative The water composition designed in Parc de IEspanya Industrial still remains one of Barcelona's largest water projects. The park itself was designed the back of one of the three main railway stations - Estació Sants ${ }^{34}$. The fact that the park came into existence testifies to one of the first victories of urba movements in Barcelona. Thanks to social protests, in the 1970 s in the place of the former mill a housing estate planned by developers was never built. The area, perfectly located in terms of accessibility, was ready during the period of preparations to the Olympic Games - in $1985^{35}$.

A considerable part of the area - nearly one third is occupied by a monumental pool with fountains which separates the green park project from a busy street, located several metres above, at the back of elements characteristic for Late-Postmodernist aesthetics, such as stylised chimneys, or a slide in the shape of an iron dragon, clearly corresponding to the tradition of Barcelona's Art Nouveau (modernisme) and the leading projects of that epoch ${ }^{36}$. The pasarella, running at the level of the railway station, the park, serves as a shortcut for pedestrians and cyclists between the intermodal hub on Plaça de $\mathrm{He}$ renni - one of the main public spaces in the district of Sants. Thanks to making creative use of the differences in altitude, the territory of the park is easily
accessible to local residents, and on the other hand it is actually invisible to users of the railway station. Thus, in spite of its difficult and onerous surrounding s $^{37}$ it can serve as a recreational space for the - a place of play and fun for children and youngsters. At the same time, the park is a forefield of the sports hall Pavelló de l'Espanya Industrial, where during the mpetition were held.

Barcelona is a compact city, where the all too dense urban tissue is directly adjacent to natur green areas (or transformed by man only to a minor extent) in the National Park on the Collserola the greenery did not play a key role in shaping the urban structure of the city, and municipal parks were a true rarity ${ }^{38}$. And all this despite the laud tial extension plan from 1859. Agricultural areas, 
wodne ${ }^{39}$ znikły zasypane, lub skanalizowane pod brukiem na nowo wytyczanych ulic. Woda uzytkowa, wspoltworząca krajobraz miasta i małych miasteczek, ktore po połączeniu przez ortogonalną siatkę Eixample utworzyły wspó́czesną Barcelonę, przestała pełnic jakąkolwiek rolę $w$ strukturze przestrzennej i w warstwie znaczeniowej metropoliijo.

W realizowanych w Barcelonie sporadycznie założeniach zielonych niezwykle rzadko wykorzystywano wode w sposób dekoracyjny, co ma swoje uzasadnienie w uwarunkowaniach klimatycznych ${ }^{41}$. Tym ciekawsze wydaja sie przytoczone w teky parków, w których założenia wodne staty sietylko pozorne wbrew logice i zrównoważonemu rozwojow miasta- gón wm spow logice i zo zorganizowani prestzen

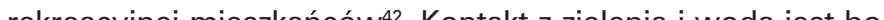
wiem koniezny dla prawidowego funkcionowania czowiek wien konecray dia prawidowe i

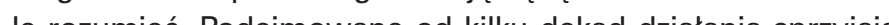
rozwojowi publicznown red kilku dekad dzila metropoli. projezych terenow zielonyeh w miescie i calej

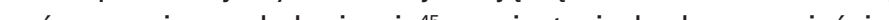
zón kore niema na co dzien boryka się z problemami z zaopatzeniem w wodę. Wydaje się, że realizacja duzych, dekoracyjnych zbionilow wody, jak tych istniejących w Parc de la Clutadella czy Parc de IEspanya Industrial, nie będzie już możliwa. Tym ważniejsze pozostaje pytanie o możliwosc ewentualnego przycieków wodnych, chociazby w sposób dekoracyjny.

PRZYPISY

1. Duzo wagi poświeca tej problematyce wielu autorów, zarówno w pracach
przekrojowych (Z. Ziobrowski,2012; L.Nyka,2013; A. Böhm,2016; I. Mirono-

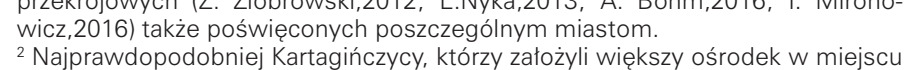

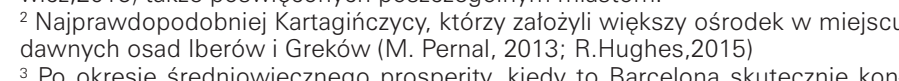
kurowala z Genua i Wenecją w handlu śródziemnomorskim, podporzadkowuija

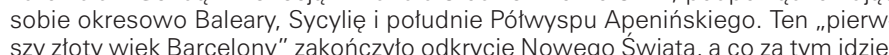
takiz przeniesienie zamorskiego handlu Hiszpanii z portów śródziemnomorskich
do otwartych na Atlantyk-Kadyksu i Sewilli i J.Busquets, 2005; J.Parcerisa Bundo otwartych na Atlantyk- Kadyksu IS Sewili (J.Busaudets,
dó, 2014; R. Hughes ,op.cit.; a takie M. Gyurkovich;2016)

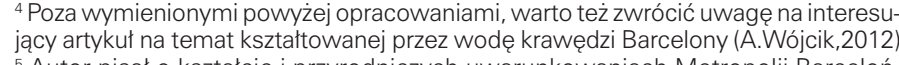
skiej na tamach Housing Environment $\mathrm{w}$ roku 2016 - patrz: Literatura.
6
6 obserwować tez winnych czéściach Barcelony-Rambla del Poblenou, czy innych
miastach-jak np. w Gironie, czy Figueras (R. Hughes, op.cit.; K. Hofert, 2012) 7 Pod koniec średniowiecza Barcelona przekroczyła Las Ramblas, a zachodnia
część starego miasta (Ciutat Vella) czyli EI Raval, gdzie usytuowane byyly liczne

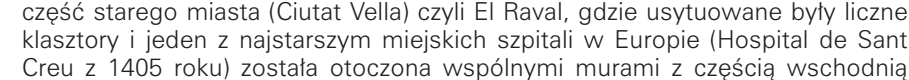

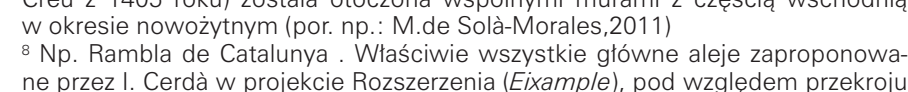
powielaty typologie rambli. (por. wtaścivie wszystkie pozycje bibliograficzene do tyczace rozwoju urbanistycznego Barcelony - $w$ tym szczególinie J. Busquets,
op.citi:; M. de Solà-Morales, op.citi:; J.Parcerisa Bundó, op.cit:; A. Sotoca, O. Carracedo, 2015)

9 W obszarach nowych zespotów mieszkaniowych budowanych od lat 60. XX
wieku (A. Sotoca led) 2012)

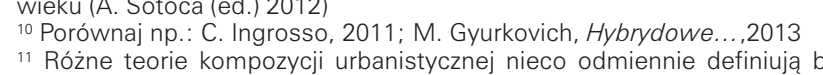

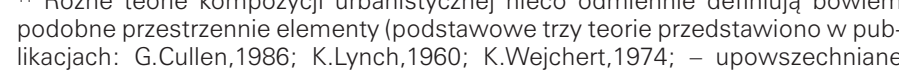

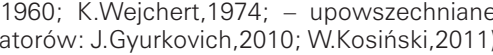

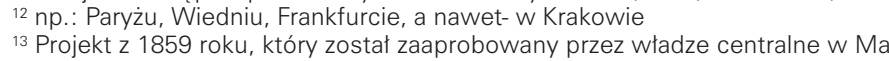
drycie i stat się wzorem dla wielu innych miast hiszpańskich wywart tez ogromny which for centuries had constituted the foundation of the cily, were nearly completely built up. Natur and articial watercourses accompanying them disappeared, buried or canalised under the sucreating the landscape of the city and small town which having been linked by the orthogonal grid of Eixample formed the Barcelona of today, stopped playing any role whatsoever in the spatial structure and in the layer of meaning of the metropolis ${ }^{40}$. In green projects, sporadically implemented in Barative element, which can be justified by the accal matic conditions ${ }^{41}$. Therefore, the examples of parks discussed in this paper, where water projects have become - only seemingly contrary to the logic and sustainable development of the city - the main way to organise recreational space for city residents proper functioning of man, especially in the ised environment ${ }^{+3}$. Authorities of Barcelona and of the metropolitan region ${ }^{44}$ seem to understand this necessity perfectly well. Measures undertaken for several decades now foster the development of green public areas in the city and in the entire me tropolis. Projects and implementations also becom necessary in the city that nearly every day has to face water supply problems. It seems that building big decorative waterbodies, like the ones located in Parc de la Ciutadella or Parc de l'Espanya Industrial, will no longer be possible. Therefore, the question col wationg the possidy of decorative purposes, is all the more important.

ENDNOTES

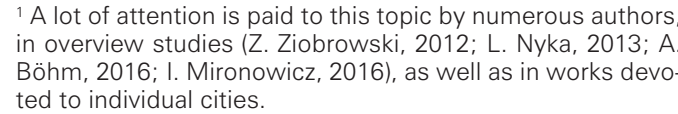
${ }^{2}$ Most probably Carthaginians, who founded a bigger centre
in the place of former settlements of lberians and Greeks (M. Pernal, 2013: R. H. Hughes, 2015)
3 A Ater the period of the medieval

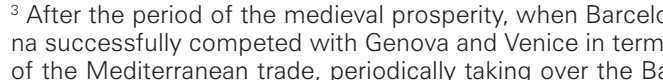
of the Mediterranean trade, periodically taking over the B
learic Islands, Sicily, and the southern part of the Athe learic Islands, Sicily, and the southern part of the Apennine
Peninsula. This first 'golden age of Barcelona' ended whe the New World was discovered, and consequently when the
overseas trade of Spain was transferred from its Mediterranean ports to the ones open towards the Atlantic Ocean
- Cadiz and Seville (J. Busquets, 2005; J. Parcerisa Bundo 2014; R. Hughes, op. cit.; as well as M. Gyurkovich: 2016 ,
${ }^{4}$ Besides the studies referred to above, it is worth paying attention to an interesting article devoted to the edge of $B$ 5 The author rrote about the shapae and natural conditions of
the Barcellona Metropolis in Housing Environment in 2016 - see: Literature.
6 Wonderful examp

ry can be observed also in other parts of Barcelona - Rambla del Poblenou, or in other cities, like e.g. in Girona, or Figue
ras (R. Hughes, op. cit.; K. Hofert. 2012) 7 Towards the end of the Middle, Ages Barcelona went bey-
ond Las Ramblas, and the western part of the old town (Ciutat Vella), El Raval, with numerous monasteries and one o
the oldest municipal hospitals in Europe (Hospital de San Creu from 1405 ), was surrounded with city walls shared with
the eastern part in the modern times (cf. e.g.: M.de Solàthe eastern pa.
Morales, 2011).
$8 \mathrm{E}$. .g.: Ramble 8E.g.: Rambla de Catalunya. Actually, all the main avenues
proposed by I. Cerdà in his extension project (Eixample) imitopod the typology of the ramblas in terms of the sectional
view. (Cf.: actually all references devoted to the urban de-
Wptyw na rozwiazania przestrzenne w skali globalnej.
14 Integrujaca Barcelone (Ciutat Vella) z r rozrzuconym ności projektu i poszzanowaniu Iolkalnych tradycji urbanistycznych i i uralistycz-

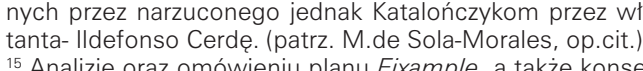
Annilizie oraz omowieniu planu Eixample, a takize konsekwenciji jego wrowa-

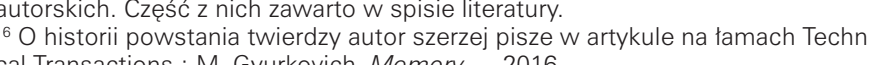

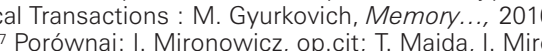

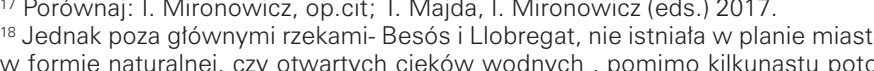

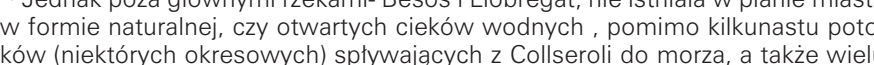
kow (niektornych okresonych) splywających z Collseroli do morza, a atakie wielu
istniejacym kanatom nawadniajacym pola i doprowadzajacym wode do celów przemystowych, Które przecinath nizinne terenn nadmorskie.
in No. na Placa Espanya, na przecięciu Gran Via i Passeig de Gracia, czy na skwerze koto bazyliki Sagrada Familia

- Intensywność w niektórych spośŕ́d centralnie ulokowanych kwartatów E.

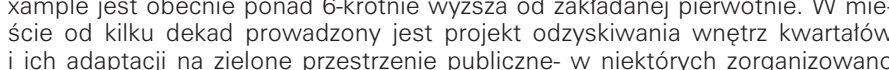
ich adaptacii na zielone przestrzenie publiczne- $w$ niektórych zorganizowano
elementy wodne, $w$ tym np. sadzawko - basen $w$ Jardin de la Torre dels Aigues elementy wodne, $w$ tym np. sadzawko - basen $w$
(o czym autor pisat na tych tamach w roku 2012-(9))

${ }_{21}^{21}$ C. Ingrosso, 2011; K. Hofert, 2012;
22 Jak np. rewitalizacja dawnych rzeżn miejskich przy Plaça Espanya i ich trans-

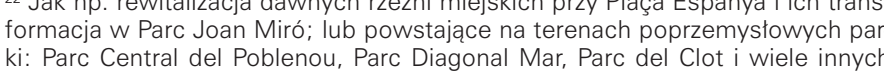

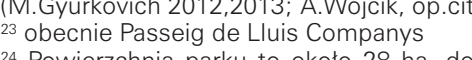

${ }_{24}^{2}$ Powierzchnia parku to okoto 28 ha, do czego można doliczyć tereny zielone (dawniej wystawowe) pomiedzy ceglanym, neomauretańskim Arc de Triomf
(dawna brama wejsciowa a a Wystawe Swiatowa- proj. J. Vilaseca i Casanovas). a Parc berama liutadellaw wrdtuz wspomnianej promenady
${ }_{25}$ Mnicha (Myiopsitta monachus)

ukońctone w 1888 roku

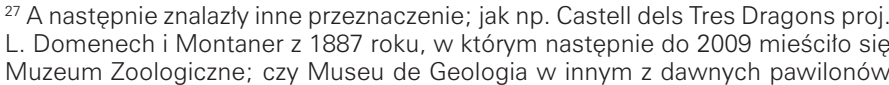
Muzeum Zoologiczne, czy Museu de Geologia w innym z dawnych pawilonów
(por. M. P.ernal, op.ici.). 28 Takich jak Parlament Kataloński w dawny arsenale- najwiekszym z zachowa-
nych obiektów Cytadeli (pozzostate to wciazz dziatająca kaplica oraz dawny Patac Gubernatora $)$
22 Zakkadato one rezygnacje z $z$ krat na rzecz fos i i wyniesienia dróg dla zwiedzaja

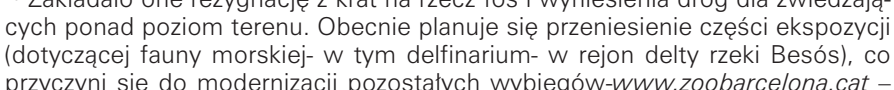
(dotyczacej fauny morskiej- $w$ tym delfinarium- $w$ rejon delty rzeki Besós), co
pryzcyyni sie do modernizacji pozostatych wybiegów-www.zoobarcelona.cat
dostęp 13.01 .2018 作

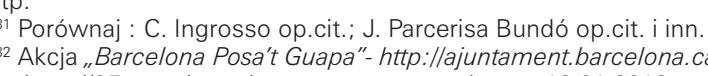

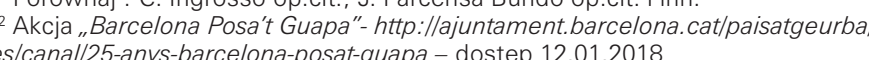
33 Dane za: www.bcn.cat- dostep 10.05.2012

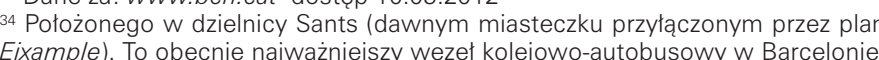
zintegrowany $z$ systemem metra i koli metropolitallyych oraz autobusonym
transportem miejskim, doskonale powizzany z lotniskiem miedzynarodowym Prat.-ibidem
35 Projektantem parku iest baskijiski architekt - Luis Peña Ganchequi - www. bar celonaturisme.com/ww/en/page/529/parc-de-lespanya-industrial.html - dostep

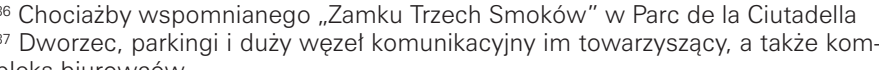
38 Pomimo, że jak dowo
tynentu bywato inaczej Strumienie i kanaty nawadniajace, a na obszarze nadmorskich bagien w dzisiej-

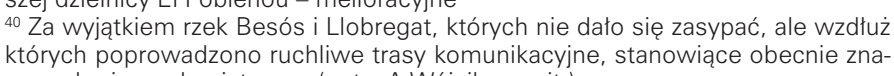
czace bariery urbanistyczne (patrz A. Wojocicik, op.citi.)

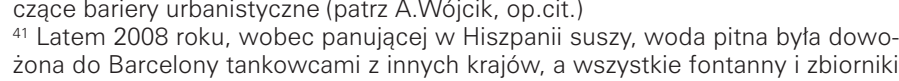
dekoracyine $w$ mieście odlaczono od sieci. Od tego czasu wprowadzono sze
reg ograniczén $w$ uzytkowaniu wody (potencialnie pitnej) $w$ przestrzeniach pub-

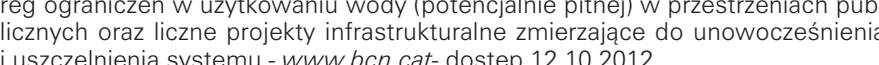

odgrywaja ważna role kompozycyina są Parc Diagonal Marl por. M. Gyurkovich Public Spaces...,2013,op.cit.) oraz Parc Central de Nou Barris, o którym autor
pisat na tych tamach w 2016 roku (M. Gyurkovich. Parc Central de Noy Barris

op.cit.) - obydwa założone na przetomie wieków XX i XXI velopment of Barcelona, including particularly $J$. Busquets,
op. cit.; M. de Sola--Morales, op. citit; J.Parcerisa Bundo, op. In the areas of new housing complexes erected since the
1960 (A. Sotoca (ed.) 2012) 10 Cf. e. G.: C. Ingrosso, 2011; M. Gyurkovich, Hybrydowe... 2013

tially similar eleoments in a slightly different tially similar elements in a slightly different way (the thre
basic theories are presented in the following publications:
G. Cullen, 1986; K. Lynch, 1960; K. Wejchert, 1974; - subse quently disseminated and developed by their continuator
1. Gyurkovich. 2010. W. Kosiński. 2011) 12 E.g. in Paris, Vienna, Frankfurt, and even in Cracow.
${ }^{13}$ The design from 1859 , approved by the central autho 13 The design from 1859, approved by the central authorities
in Madrid, became a model for many other Sanansh cities
and had an immense effect on spatial solutions in the global Scale.
14 Integrating Barcelona (Ciutat Vella) with towns peppering
the Barcelona Plain, the effects of which in the form of irregularities of the grid testify to the uniquenesss of the design and IIdefonso Cerdà, who after all was imposed on the Catalans by
the central authorities (see: M.de Sola-Morales, op. cit.) the central authorities (see: M.de Sola-Morales, op. cit.)
${ }^{15}$ Hundreds of publications worldwide, also by the Author. "Hundreds of publications worldwide, also by the Autho
have been devoted to the analysis and discussion of the have been devoted to the analysis and discussion of the
layout of Example, as well as of the consequences of its
implementation for the development of the spatial structure of Barcelona and for the development of urban planning as
such. Some of such publications are included in the list of references.
16 The Author writes more about the history of the fortress
in his paper in Technical Transactions: M. Gyurkovich, Memory.., 2016 . ${ }_{18}$ However, besides the main rivers - the Besós and the Llobregat - it did not exist on the city map in the natura
form, or as open watercourses, despite over ten streams (some of them periodicall flowing down from the Collserola
range to the sea, as well as many existing canals irrigating
the fields and providing water for industrial purposes, which intersected the coastal plains.

19. E.g. at Plaça Espanya, at the intersection of Gran Via and
Passeig de Gracia, or on the square near the Sagrada Fami20
20 For several decades now the city has been implementing
a project of reclamiming guarter interiors and their adanta a project of reclaiming quarter interiors and their adapta-
tion to the functions of green public spaces - in some of tion to the functions of green public spaces - in some of
them water features have been organised, e.g. a pool-pond in Jardin de la Torre dels

${ }^{21}$ C. Ingrosso, 2011; K. Hofert, 2012;
${ }^{22}$ Like e.g. revitalisation of former municipal slaughterho-
sues at Plaça Espanya and their transformation into Parc uses at Plaça Espanya and their transformation into Parc
Joan Miro; or parks coming into being on postindustrial areas: Parc Central del Poblenou, Parc Diagonal Mar, Parc
del Clot, and many others (M. Gyurkovich 2012,2013; A Nojicik, op.cit.
${ }^{3}$ T.

24 Today Passeig de Lluis Companys
2 The area of the park is ca. 28 ha, in
Iformar

(former exhibition areass between a brick structure of the
Neo-Moorish Arc de Triomf (formerly an entrance gate the World's Fair, designed by J. Vilaseca i i Casanovas), and ${ }_{5}^{2}$ Monk parakeet (Myionsitta monachus)
5

${ }^{26}$ Completed in 1881

27 And then they found other types of use, like e.g. Castell
dels Tres Dragons designed by L. Domenech $i$ Montaner from 1887, which until 2009 housed the Zoological Muse-
um; or Museu de Geologia in another former pavilion (cf.: M. Pernal, op. cit.).
${ }_{28}$ Such as the Parl

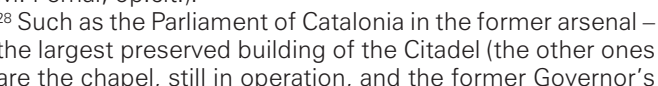
Palace).
Palt was based on a concept of resigning from bars in favour of moats and elevating routes for visitors over the ground
level. Nowadays it is planned to move a part of the exposition (devoted to marine fauna - including a dolphinarium
- to the area of the delta of the Besós river), which will con- to the area of the delta of the Bescós riverl, which will cor-
tribute to the modernization of other animal enclosures -
www.zoobarcelona.cat - access on 13 January 2018. 
43 Co zostało wielokrotnie udowodnione w licznych publikacjach naukowych (A. Januchta-Szostak, 2008; J.Gyurkovich, op.cit.; L.Nyka, op.cit.; W.Kosiński, op. cit., a także-2016; A. Zachariasz, op.cit. i wiele innych)

44 Obecną strukturą administracyjną, zarządzającą obszarem metropolitalnym jest utworzona w roku 2011 Area Metropolitana de Barcelona, skupiajaca oprócz Barcelony 35 miast i miasteczek, która łączy kompetencje trzech działających uprzednio organów administracji regionalnej.- wWW.amb.cat-dostęp 14.01.2018

45 Porównaj monumentalny konkurs na 16 zielonych "bram do Collseroli”, z których w niektórych miejscach starano się odtworzyć i przywrócić do życia dawne strumienie spływające z gór do morza. Prace zostały szczegółowo omówione w obszernej publikacji (A.Sotoca, O.Carracedo, op.cit.).

\section{LITERATURA}

1] Böhm A., O czynniku kompozycji w planowaniu przestrzeni, Wyd. PK, Kraków 2016 [2] Busquets J., Barcelona. The urban evolution of a compact city, Nicolodi; Harvard University Graduate School of Design, Rovereto, Cambridge, MA 2005

[3] Busquets J., Urban compositions: City Design in the 21st Century, [in:] Graafland A., Kavanaugh L.J. (eds.), Crossover. Architecture, Urbanism, Technology, 010 Publishers, Rotterdam 2006

[4] Costa G., Barcelona 1992-2004, GG, Barcelona 2004

[5] Cullen G., The Concise Townscape, The Architectural Press, London 1986

[6] Gyurkovich J., Architektura w przestrzeni miasta. Wybrane problemy, Wyd. PK, Kraków 2010

[7] Gyurkovich M., 22@Barcelona - The City of Knowledge Civilization, Technical Transactions, Seria $A$, z. 4A/2012 (rok 109)

[8] Gyurkovich M., Hybrydowe przestrzenie kultury we wspótczesnym mieście europejskim, Wyd. PK., Kraków 2013

[9] Gyurkovich M., Social Space and Public Space in the Central Residential Districts of Barcelona, Srodowisko Mieszkaniowe/ Housing Environment, no. 10/2012

[10] Gyurkovich M., Public Spaces in Knowledge Civilization Cities- Part One: Barcelona ,Technical Transactions, Series A, no. 2A/2013 (year 110)

[11] Gyurkovich M., Memory of the City- Layers of the City. Spanish Examples, Technical Transactions, Series A, no. 2A/2016 (year 113)

[12] Gyurkovich M., Parc Central de Nou Barris as an element of the greenery system of the hybrid urban structure of the Barcelona Metropolis, Środowisko Mieszkaniowe/ Housing Environment, no. 17/2016

[13] Hofert K., Przestrzeń publiczna w mieście śródziemnomorskim: uwag kilka na temat Barcelony, Czasopismo Techniczne, z. 2-A/2010 (rok 107)

[14] Hughes R., Barcelona, Wyd. Magnum, Warszawa 2015

15] Ingrosso C., Barcelona. Architecture, City and Society 1975-2015, Skira, Milano 2011

[16] Januchta-Szostak A., Błękitna krew miasta. Woda jako ożywcza siła przestrzeni publicznych, Czasopismo Techniczne, z. 3A/2008 (rok 105)

[17] Kosiński W., Miasto i Piękno Miasta. Wyd. PK, Kraków 2011

[18] Kosiński W., Zieliński M., Urbanistyka krajobrazu i krajobraz urbanistyczny. Teoria. Praktyka. Edukacja, Przestrzeń i Forma nr 25/2016

[19] Kriken J.L., Enquist P., Rapaport R., City Building. Nine Planning Principles for the Twenty-First Century, Princeton Architectural Press, New York, 2010

[20] Lynch K., The Image of the City, The MIT Press., Cambridge Mass. 1960

[21] Majda T, Mironowicz I. (eds.), Manifesty urbanistyczne, BU 15, TUP, Warszawa 2017

[22] Miralles R., Sierra P., Barcelona, Arquitectura contemporània 1979-2010, Editions Poligrafa, Barcelona 2010

[23] Mironowicz I., Modele transformacji miast, Oficyna Wydawnicza Politechniki Wrocławskiej, Wrocław 2016

[24] Nyka L., Architektura i woda- przekraczanie granic, Wyd. PG, Gdańsk, 2013

[25] Parcerisa Bundó J., Barcelona, Urbanisme Segle XX, Vigila el mar, vigila el muntanyes, MONTABER, Barcelona 2014

[26] Pernal M., Spacerownik historyczny-Barcelona-Miasto-Ludzie-Książka-Film, Wyd. Agora, Warszawa 2013

[27] de Solà-Morales M., Deu Lliçons sobre Barcelona, COAC, Barcelona 2011

[28] Sotoca A.(ed.), After the Project- updating Mass Housing Estates. // EcoRehab, Barcelona 2011, UPC, Barcelona, 2012

[29] Sotoca A., Carracedo O., Naturban. Barcelona's natural park a rediscovered relation. 10 reflections, 111 proposals , COAC, Barcelona 2015

[30] Wejchert K., Elementy kompozycji urbanistycznej, Arkady, Warszawa 1974

[31] Wójcik A., The memory of a city. Barcelona - a city on the edge, Technical Transactions, Series $A$, no. 4A/2012 (year 109)

[32] Zachariasz A., Zieleń jako wspótczesny czynnik miastotwórczy ze szczególnym uwzględnieniem roli parków publicznych, Wyd. PK, Kraków, 2006

[33] Ziobrowski Z., Urbanistyczne wymiary miast, IRM, Kraków 2012
30 Railway infrastructure, motorways, extension of international airports, etc.

${ }^{31}$ Cf.: C. Ingrosso op. cit.; J. Parcerisa Bundó op. cit., and others.

32 Campaign 'Barcelona Posa't Guapa' - http://ajuntament.barcelona.cat/paisatgeurba/es/canal/25-anys-barcelona-posat-quapa - access on 12 January 2018.

33 Data after: www.bch.cat - access on 10 May 2012.

${ }^{34}$ Located in the district of Sants (formerly a little town incorporated in the plan of Eixample). Today it is the most important railway and coach hub, integrated with the system of subway, metropolitan railway, and municipal buses, perfectly linked with the international airport of El Part. - ibidem

35 The designer of the park is a Basque architect, Luis Peña Ganchegui - www.barcelonaturisme.com/wv3/ en/page/529/parc-de-l-espanya-industrial.html - access on 14 January 2018.

${ }^{36}$ Like e.g. the aforementioned 'Castle of the Tree Dragons' in Parc de la Ciutadella.

${ }^{37}$ A railway station, a car park, and a large intermodal hub that accompanies them, as well as a complex of office buildings.

${ }^{38}$ Despite the fact that - as evidenced by A. Zachariasz (2006) - at times it was quite different in many other cities on the continent.

39 Streams and irrigation canals, and drainage canals in the area of coastal marshes, in the today's district of El Poblenou.

${ }^{40}$ Except for the Besós and the Llobregat rivers, which could not be buried, but along which busy traffic routes were designed, which today constitute considerable urban barriers (see: A. Wójcik, op.cit.).

${ }^{41}$ In the summer of 2008 , due to the drought that af fected Spain, potable water was delivered to Barcelona in tankers from other countries, and all fountains and decorative waterbodies were disconnected from the pipelines. Ever since then, a number of restrictions concerning the use of (potentially potable) water in public spaces have been implemented, as well as numerous infrastructural projects aiming to modernise and improve the tightness of the system - www.bcn. cat- access on 12 October 2012.

42 Other relatively big parks in Barcelona, where water features play an important compositional role, are Parc Diagonal Mar (cf.: M.Gyurkovich, Public Spaces... ...2013,op.cit.) and Parc Central de Nou Barris, about which the Author wrote herein in 2016 (M. Gyurkovich, Parc Central de Nou Barris..., op.cit.) - both established at the turn of the $20^{\text {th }}$ century.

43 Which has been demonstrated many times in numerous scientific publications (A. Januchta-Szostak, 2008; J. Gyurkovich, op.cit.; L. Nyka, op.cit.; W. Kosiński, op. cit., as well as -2016; A. Zachariasz, op.cit., and many others).

${ }^{44}$ The present administrative structure that manages the metropolitan area is Area Metropolitana de Barcelona, founded in 2011, which besides Barcelona associates 35 bigger and smaller towns and which combines the competences of three previous regional administration bodies.- WWW.amb.cat - access on 14 January 2018.

${ }^{45} \mathrm{Cf}$ : monumental competition for 16 green 'gates to Collserola', in which in some locations attempts were made to reconstruct and revive former streams flowing from the mountains to the sea. The works have been discussed in detail in a comprehensive publication (A. Sotoca, O. Carracedo, op. cit.) 